\title{
The process of embedding a small firm in its industrial context
}

\author{
Eleanor Shaw, Juliette Wilson and Tobias Pret
}

University of Strathclyde, UK

\begin{abstract}
This article explores the activities involved in embedding a small firm in its industrial context. Inductive analysis of longitudinal, case study data collected from a small firm in the creative industries highlights the use of networks and networking as embedding mechanisms. Key emergent themes include the impacts of pre-embeddedness (defined as the sum of all cultural, social and symbolic capital accessible to the founding team prior to business start-up), the vision and network orientation of the founding team and their strategic use of networking. The interplay between these conditions and activities is revealed as important in building legitimacy, which is critical for embedding a firm in its industrial context. This article extends knowledge of embedding beyond the initial phase of new venture creation and highlights the emergent and evolving dynamics behind this process.
\end{abstract}

\section{Keywords}

embeddedness, social network theory, capital theory, creative industries, networking

\section{Introduction}

It has long been recognised that embeddedness in different networks and contexts strongly affects the creation, survival and growth of small firms (Aldrich and Zimmer, 1986; Birley, 1985; Granovetter, 1985). Accordingly, there has been sustained interest in investigating networking (Greve and Salaff, 2003; Jack et al., 2010) and embedding processes (Jack and Anderson, 2002; Uzzi, 1997). ${ }^{1}$ However, recent studies on the interplay between entrepreneurship and place (Korsgaard et al., 2015), communities (McKeever et al., 2015) and markets (Ram et al., 2008) demonstrate the need for deeper explorations into 
the nexus between small firms and the contexts in which they are embedded (Welter, 2011). Research on small firm networks has, to some extent, developed our knowledge of this relationship (Johannisson et al., 2002; Hite and Hesterly, 2001). For example, prior research reveals that industry specific norms can lead small firms to engage in networking activities despite competitive industrial dynamics (Shaw, 2006). Furthermore, embeddedness within networks can increase entrepreneurial success by providing access to resources and competitive advantage without significant capital investment (Batjargal, 2003; Hite, 2005).

Despite these contributions, research on small firm networks has yet to fulfil its potential for advancing our understanding of embedding processes. A focus on network structures and a historic overuse of positivist research approaches have left enduring gaps in our knowledge of the dynamics between small firms and the networks in which they are embedded (Jack, 2010; Slotte-Kock and Coviello, 2010). Additionally, most studies of small firm networks focus on the personal contact networks of the founding entrepreneurs (Batjargal, 2003; Dubini and Aldrich, 1991; Lechner and Dowling, 2003), while few consider the involvement of employees and their networks in the embedding process (Maurer and Ebers, 2006; Witt, 2004). Similarly, there remains limited understanding of the impact of founding conditions and networking activities on embedding processes and firm development post start-up (Anderson et al., 2010; Elfring and Hulsink, 2007; Jack et al., 2010). While access to resources is a well-documented outcome (Hite, 2005; Sullivan and Ford, 2014), other aspects of networking are less well understood. Within the small firm literature, the use of networks as an embedding mechanism, the interactions needed to acquire network benefits and the role of entrepreneurial agency in embedding processes remain vague (Grossman et al., 2012; Hoang and Antoncic, 2003; Uzzi and Gillespie, 2002).

This article addresses these research gaps by exploring the use of networks and networking activities in the process of embedding a small firm in its industrial context. We use social network theory (Mitchell, 1969) and Bourdieu's (1986) capital theory to frame our analysis. By employing a case study 
approach and collecting data over an 18-month period, we extend knowledge of embedding beyond the initial phase of new venture creation and evidence its emergent, evolving nature. We advance theoretical understanding of embeddedness by revealing the importance of pre-embeddedness, which we define as the sum of all cultural, social and symbolic capital accessible to the founding team prior to business startup. Furthermore, we highlight the impact of the multiple, combined networks of several team members on the embedding process of an entrepreneurial firm (Maurer and Ebers, 2006; Witt, 2004). We demonstrate that the combination of a strong network orientation and portfolio of strategically targeted networking activities is integral to this process. Thus, we provide deeper understanding of the role of agency and the effects of micro-level networking activities on embedding processes. Finally, we develop a conceptual model that illustrates the interplay between pre-embeddedness, networking and embedding activities and the ongoing outcomes of these processes.

Following this introduction, we consider the theoretical framing of our study. Next, we provide a description of our methods, including details of the case firm, data collection and inductive analysis. We then analyse and discuss the findings of our empirical study before drawing conclusions and identifying implications for research and practice.

\section{Theoretical Background}

\section{Embeddedness}

Granovetter (1985) convincingly argues that economic theory has adopted an 'undersocialized' approach to human behaviour and that researchers should pay closer attention to both the contexts in which economic exchanges occur and the interactions required to facilitate these exchanges. This perspective has been echoed by a growing number of researchers, who assert that entrepreneurship is 'intrinsically intertwined with the very fabric of contemporary society' (De Clercq and Voronov, 2009: 395), that context matters (Welter, 2011; Zahra et al., 2014) and that 'entrepreneurs are embedded in networks, 
places and communities which socially frame resources and opportunities' (McKeever et al., 2015: 50). Collectively, this research recommends a greater focus on the dynamic between entrepreneurs and the contexts in which they are embedded (Chalmers and Shaw, 2015).

Emerging studies have offered mixed but nonetheless important insights into the complexity of contextual embeddedness. Numerous studies illustrate the benefits of embeddedness, including access to resources, information and emotional support (Casson and Giusta, 2007; Ozcan and Eisenhardt, 2009; Slotte-Kock and Coviello, 2010). Research has also shown that embeddedness can be a liability when social responsibilities supersede economic imperatives: described by Uzzi (1997) as 'overembeddedness'. Whatever its consequences, embeddedness has proven to have a disproportionate impact on the sustainability and growth of small firms, due to their reduced bargaining power, smaller scale and limited market share (Batjargal, 2003; Hite and Hesterly, 2001).

Clearly, embeddedness is significant for small firms (Korsgaard et al., 2015; Parkinson et al., 2016), requiring deeper examination of the dynamics between these firms and their contexts. Indeed, few studies have empirically investigated this relationship (cf. Jack and Anderson, 2002; McKeever et al., 2015), as it is challenging to operationalize the concept of embeddedness (Uzzi, 1997). Scholars have implemented different theoretical lenses to overcome this issue. For example, structuration theory (Giddens, 1984) has been used to study the effects of embeddedness on entrepreneurial processes (Jack and Anderson, 2002) and on network formation (Manning, 2010). Other studies have drawn on practice theory (Bourdieu, 1977; Schatzki, 2002) to explore how nascent entrepreneurs build legitimacy when entering new markets (De Clercq and Voronov, 2009) and to understand how they acquire resources (Keating et al., 2014) While both of these theoretical approaches acknowledge the duality of entrepreneurial agency and macro-level structures (McKeever et al., 2015; Ozcan and Eisenhardt, 2009), neither are without their criticisms in this respect. As De Clercq and Voronov (2009) argue, 'both theories may focus too much on the role of field-level structural arrangements and therefore may not devote 
sufficient attention to the role of micro-level individual behaviour' (p. 409). Simply put, by failing to consider entrepreneurial agency in sufficient detail, neither perspective is able to fully capture the richness of such agency or its impact on the structures in which small firms are embedded.

\section{Social network theory}

Cognisant of the shortcomings of alternative approaches, we draw on Social Network Theory (SNT) to frame our study (Mitchell, 1969). SNT has a long history of application within the field of entrepreneurship, largely due to its potential for operationalizing embeddedness (Hallen and Eisenhardt, 2012; Phillips et al., 2013). SNT conceives society as comprising a fluctuating network structure of overlapping relationships which connect individuals, groups and organisations (Vardaman et al., 2012; Wong and Boh, 2010). As such, it can be used to analyse the networks of differing analytical units, from individual entrepreneurs to entrepreneurial ventures (Shaw, 2006). Importantly, SNT acknowledges the dynamic between network structures and interactions (McAdam et al., 2014), which has emerged as a popular, if debated topic within the small business literature (Jack et al., 2010).

Building on Granovetter's (1973) 'strength of weak ties' proposition, some scholars have argued that entrepreneurs benefit from being centrally located within loosely connected networks that comprise mainly weak relationships (Vardaman et al., 2012). ${ }^{2}$ Early studies indicated that embeddedness in looser networks can grant access to greater amounts of resources (Aldrich and Zimmer, 1986; Birley, 1985). However, most ventures are embedded within networks containing a variety of weak and strong ties and areas of both network density and structural holes (Burt, 1992; Hite and Hesterly, 2001). ${ }^{3}$ Informed by the findings of empirical studies which challenge the strength of weak ties thesis (Antcliff et al., 2007), there have been repeated calls for greater reflexivity when considering the benefits of strong and weak ties (Hoang and Antoncic, 2003; Slotte-Kock and Coviello, 2010). Furthermore, there have been suggestions that both are likely to be beneficial at different stages in the entrepreneurial process (Jack, 2010). 
While studies of small firm networks informed by SNT have advanced understanding of the importance of networks (Jack, 2005; Ozcan and Eisenhardt, 2009; Sullivan and Marvel, 2011), they have also been criticised for a focus on network structures. A key reason for this is the ease with which network structures can be investigated; they are more readily measured, quantified and analysed (Salancik, 1995). Furthermore, network researchers have exhibited a preference for positivist approaches (Jack, 2010, Slotte-Kock and Coviello, 2010). However, as the field evolves, the benefits of using alternative approaches and qualitative methods for exploring complex entrepreneurial phenomena are increasingly recognised (Suddaby et al., 2015). In particular, research has demonstrated the value of critical realist (Lee and Jones, 2008), social constructionist (Karataş-Özkan and Chell, 2010) and interpretivist approaches (Al-Dajani et al., 2015) for understanding networking and embedding processes.

\section{Capital theory}

A common theme within much of this emergent research is an interest in understanding the resources contained within small firm networks (Hite, 2005; Kilduff and Brass, 2010; Sullivan and Ford, 2014). However, one of SNT's shortcomings is a lack of conceptual clarity regarding the specific types of resources that can be accessed through networks. Recognising the importance of both tangible and intangible resources, studies have begun to use Bourdieu's (1986) capital theory to explore the variety of resources small firms can acquire by interacting with others in their networks. We build on such research (cf. Jayawarna et al., 2014; Karataş-Özkan, 2011; Stringfellow et al., 2014) and draw on capital theory to inform our study.

Bourdieu (1986) conceives of four forms of capital: economic, cultural, social and symbolic. Economic capital materialises as financial resources, such as money, and other business assets (both tangible and intangible). In order to generate income, entrepreneurs must usually convert other types of capital into economic capital (Pret et al., 2015). Thus, it is often described as the most critical asset for small firms (Terjesen and Elam, 2009). Bourdieu's (1986) conceptualisation of cultural capital is more 
complex. He identifies three types: embodied, which refers to personal dispositions; objectified, which takes the form of cultural goods; and institutionalised, which is conceived as educational qualifications (McLeod et al., 2009). As it encompasses educational background, cultural capital is often compared to the concept of human capital (Becker, 1964), which has attracted some attention within the small business literature (Davidsson and Honig, 2003; Jayawarna et al., 2014). Social capital represents all the resources that can be accessed through durable networks of relationships (Bourdieu, 1986); it exists within networks and can be acquired and developed through networking activities, such as relationship building (Wilson et al., 2016). Within the small firm literature, social capital has received considerable attention (Stam et al., 2014). However, definitions of social capital are debated (Adler and Kwon, 2002; Nahapiet and Ghoshal, 1998), with research generating mixed results concerning the value of bonding versus bridging forms of social capital (Lee and Jones, 2008; Stam et al., 2014). ${ }^{4}$ Symbolic capital incorporates the signifiers that generate trust and convince others that the economic, cultural and social capital possessed by an individual (or firm) are legitimate and credible (De Clercq and Voronov, 2009; Stringfellow and MacLean, 2014). These signifiers vary in type: they can include customers, partners and investors and can be objectified in the form of awards and public recognition (Pret et al., 2015). The possession of symbolic capital is critical for entrepreneurs, as its ability to generate legitimacy can have a significant impact on business success (Spigel, 2016; Zott and Huy, 2007).

Another important aspect of Bourdieu's (1986) theory is that each form of capital is convertible (Pret et al., 2015). For example, it might be expected that an entrepreneur with significant experience of working within a particular industry and location will be able to convert this knowledge (cultural capital) into high levels of social capital in the form of networks and contacts (Drakopoulou Dodd et al., 2016). We argue that this convertibility is crucial, particularly for a small firm with limited financial resources. However, empirical studies that employ all four forms of capital are rare (cf. Karataş-Özkan, 2011; Shaw et al., 2013) and research that accounts for their convertibility is at an early stage (Pret et al., 2015). 


\section{Analytical summary}

Research has demonstrated the importance of the networks in which small firms are embedded (Jack and Anderson, 2002; McKeever et al., 2015; Schutjens and Stam, 2003). Networks have been shown to act as a support mechanism that can generate a range of benefits (Birley et al., 1991; Casson and Della Giusta, 2007; Grossman et al., 2012). However, enduring gaps in our understanding of small firm networks remain, with few 'detailed explanations of the content of relations and what actually goes on in and between connections' (Jack, 2010: 120). Consequently, we have yet to fully understand how networking activities can be used to support embedding processes. Cognisant of these gaps and of the challenges of operationalizing embeddedness, this article employs SNT and capital theory to explore how networks and networking activities are used to embed a small firm in its industrial context.

\section{Context and methods}

\section{Research approach}

Recognising the limitations of positivist approaches and quantitative methods for investigating small firm networking and embedding processes (Jack, 2010; Slotte-Kock and Coviello, 2010), we adopted an interpretivist perspective and undertook case study research (McAdam et al., 2014). Interpretivist research rejects the ontological separation of reality and consciousness and, instead, seeks to comprehend individual perspectives on social phenomena (Al-Dajani et al., 2015; Pret et al., 2015). Interpretivist approaches are gaining traction within entrepreneurship research (cf. Lam and Harker, 2015; Lewis, 2015; Zou et al., 2016), as they allow researchers to explore various dimensions of phenomena and processes as they unfold (Cope, 2011). As such, they are particularly well suited for getting 'close to where things happen' (Steyaert and Landström, 2011: 124) and for acquiring rich empirical descriptions (Berglund, 2015). It is important to note that the value of interpretivist research cannot be judged according to positivist criteria such as reliability, objectivity and generalisability (Leitch et al., 2010). 
Thus, we are explicit about our research design to demonstrate its 'credibility, transferability, dependability and confirmability’ (Lincoln and Guba, 1985: 189).

Our study adopted a single case design, informed by the collection of qualitative data from multiple sources (Karataş-Özkan, 2011; McAdam et al., 2014; Phillips et al., 2013). Entrepreneurship discourse has increasingly recognised the benefits of case study research when investigating complex, real-life phenomena (Chetty et al., 2014; Ozcan and Eisenhardt, 2009). Case studies are particularly useful for exploring the dynamic between entrepreneurship and networks (Hallen and Eisenhardt, 2012; Jack et al., 2010; Lechner and Dowling, 2003). As Witt (2004) argues, a shortcoming of existing network studies is their focus on individual founders. Thus, we decided to select the small firm, rather than the founder, as our unit of analysis. By adopting a single case design, we were able to gain detailed insights into the effects of the multiple, combined networks of several team members on the embedding processes of an entrepreneurial firm.

\section{Creative industries context}

There are several reasons why the creative industries are compelling sites in which to explore networking and embedding activities. Firstly, there is significant evidence of the particular importance of networks for firms within creative industries (Shaw, 2006; Townley et al., 2009). Secondly, prior research has highlighted the collaborative and supportive nature of networking behaviours in certain creative industries (Drakopoulou Dodd, 2014; Pret et al., 2015). This suggests that the creative sector may reveal more examples of successful embedding than other, more aggressive industries. Furthermore, creative industries make significant contributions to national economies (United Nations Development Programme, 2013). In the United Kingdom, the creative economy accounts for 2.5 million jobs (over $8 \%$ of total employment) and provides a range of economic, social and cultural benefits to the country (Department for Culture, Media \& Sport, 2016). As such, the sector merits examination as a principal post-industrial institution. 


\section{The case firm}

This study investigated DoArt, a small arts marketing agency located in Glasgow, Scotland. DoArt operates as a regional audience and marketing research agency, working for a range of arts organisations spanning the private, public and third sectors. Clients pay project fees or annual subscriptions for a package of research intelligence, marketing training, networking events and strategic consultancy, all relating to the marketing of the arts. Over the course of 18 months following its establishment, DoArt grew from a team of three to six. However, the small size of DoArt obscures the large and complex networks of relationships the firm developed over time. As a result of earlier studies of the creative industries in Scotland, we were familiar with DoArt's founder, Emily, who has been an active member of the creative community for over 20 years. This enabled us to negotiate privileged access to the firm and its employees. Table 1 provides an anonymised overview of participants, detailing their roles and responsibilities at DoArt.

\section{-- INSERT TABLE 1 ABOUT HERE --}

There are several reasons why DoArt was considered an 'instrumental' case that warranted investigation (Stake, 2000). As creative businesses are typically small in size and embedded in complex networks of relationships (Antcliff et al., 2007; McLeod et al., 2009; Townley et al., 2009), we anticipated that the collection of data from a creative firm would be fruitful in advancing understanding of networking and embedding processes. Furthermore, due to the extensive prior experience and reputation of its founder, DoArt was more likely to succeed at becoming embedded within the industry and thus provide rich examples of this process. Finally, our familiarity with the creative industries in Scotland facilitated access to other key actors who were connected to DoArt's staff and therefore able to provide additional insights into their practices. 


\section{Data collection and analysis}

We investigated the behaviours and experiences of participants over 18 months. This allowed us to gain a longitudinal perspective of their networking and embedding activities. Thus, our study addresses the call for research that investigates networking processes over time (Hoang and Antoncic, 2003; Slotte-Kock and Coviello, 2010). Working in pairs, we conducted a series of two to three in-depth interviews, in intervals of four to nine months, with each participant on the premises of DoArt. ${ }^{\mathbf{5}}$ Interviews lasted between one and three hours and provided large amounts of rich empirical data. Initial interviews were unstructured, allowing us to build rapport with participants and to collect significant background information (Cope, 2005). Subsequent interviews adopted a semi-structured format, focusing on how and why participants initiated, developed and maintained relationships over time. This enabled us to follow up on emerging themes (Patton, 2002). Interviews were recorded and transcribed verbatim to allow the systematic analysis of data. We collected observational data during board meetings, networking meetings and other company events. We also examined company documents, including annual reports, brochures and flyers. Accessing a range of different sources helped increase the confirmability of our study (Lincoln and Guba, 1985).

Analysis of data was carried out following the principles of interpretative phenomenological analysis (Cope, 2011). Working independently, we read and re-read interview transcripts, observation notes and other documents to familiarise ourselves with the data (Pret et al., 2015). Using the constant comparative method to consider data across participants and sources (Silverman, 2000), we identified several emerging themes, which we then discussed. As Gartner (2007) highlights, individual interpretations of the same piece of text can differ, which is why such a collaborative approach is beneficial. Next, we developed interpretive case summaries, which we shared with participants to gain their perspectives and which we used to inform our ongoing analysis (Cope, 2005). Finally, we 'recontexualized' our findings by comparing them to arguments in the extant literature (Marlow and 
McAdam, 2015: 800). This abstraction process involved moving iteratively between existing theory and our data to gain a higher level of conceptualisation (Edmondson and McManus, 2007). Appendix 1 illustrates how we moved from our raw data to the first order concepts and second order themes and provides abundant empirical evidence to substantiate our arguments. Three core themes emerged during the analysis process. They relate to (1) embeddedness prior to business start-up, (2) networking and embedding activities during firm growth and (3) networking and embedding outcomes.

\section{Findings Analysis}

Based on the analysis of participants' perspectives (see Appendix 1), we developed the conceptual model presented in Figure 1. It captures the three main dimensions involved in the process of embedding a small firm in its industrial context and acknowledges the interplay among them.

\section{-- INSERT FIGURE 1 ABOUT HERE --}

\section{Pre-embeddedness: capital distribution of team members}

The findings of this study illustrate the importance of the founding team's capital distribution for embedding a nascent firm in its industrial context. DoArt benefitted from the various forms of capital that the founder, Emily, provided and from her recruitment of a founding team possessing complementary experiences and valuable networks. These features were instrumental to the speed with which the firm became embedded within Scotland's creative industries.

Prior to establishing DoArt, Emily acquired over 20 years of experience working in Scotland's creative industries (cultural capital) and developed an 'important contact book' (social capital) that enabled her to start her own firm. When Emily asserted that 'we are quite lucky in one sense, because of my previous job roles - certainly within the City Council, I know a few people', she downplayed both the 
number and the influence of these contacts within the sector. Many of them were responsible for managing large budgets earmarked for supporting creative businesses in Scotland. Emily revealed that, before setting up DoArt, she had been assured of three sizeable contracts with separate arts organisations. This assertion initially seemed at odds with the mandate that all publicly funded bodies put bids out for competitive tendering (Vincent, 2005). However, there is evidence to indicate that, when a firm has an existing relationship with a contractor, it is more likely to secure available business funding (Shaw, 2006; Uzzi, 1997). This was the case for Emily and the contracts she secured. Emily was so well connected (social capital); had such relevant experience (cultural capital); and was so respected as a credible leader of a creative firm (symbolic capital) that she was convinced she would be awarded these contracts. This demonstrates that, in certain cases, multiple forms of non-financial capital are required to generate economic capital in the form of contracts (Pret et al., 2015). By securing these 'promises of funding', Emily was assured that she would acquire the economic capital needed to form a founding team and start her venture. Describing her recruitment of this team, Emily explained that she used three criteria: 'relevant knowledge and expertise'; 'a similar outlook and values' to her own; and 'established contacts within the industry'. Using these criteria, Emily appointed Cristie as Audience Researcher and Dorothy as Audience Developer (see Table 1).

Emily's creation of an all-female founding team was not deliberate, yet it reflects a degree of homophily (McPherson et al., 2001). However, her focus on ensuring a diversity of skills served to overcome limitations associated with homophily, including overestimating the benefits of marked similarities (Ruef et al., 2003). In fact, Emily's recruitment decisions suggest that she was aware of the advantages of combining homophily, including its potential for greater trust and understanding (Phillips et al., 2013), with the advantages of functional diversity. Also significant was Emily's decision to recruit staff with complementary forms and amounts of capital, such as experience of working within Scotland's creative industries (cultural capital) and contacts with established industry members (social capital). Their 
prior knowledge ensured awareness of industry norms and their existing networks provided direct access to the creative sector in Scotland, thus helping legitimise the firm (Lounsbury and Glynn 2001; Zimmerman and Zeitz, 2002). As Dorothy explained, when asked about her work prior to joining DoArt:

I was basically in a YTS [Youth Training Scheme]. I got a placement at [Ballet Company], to do marketing training, was there for $1 \frac{1}{2}$ years and then the boss, who was there, she took me off to [Opera House], so I was there for 12 years and I worked my way up from Marketing Assistant to Officer Assistant, then Marketing Manager, so I was looking after a small team ... It involved the marketing of the Opera, locally, nationally and internationally, so a lot of stuff.

Furthermore, as Cristie and Dorothy had not previously worked together, their recruitment helped bridge structural holes in the firm's network (Burt, 1992; Hite and Hesterly, 2001). By selecting employees with different backgrounds, Emily also reduced the likelihood of over-embeddedness (Uzzi, 1997). As Dorothy noted, 'I had heard of her [Emily]; I knew she was at the [Museum], but I did not move in the same circles. She was more Council and I was more non-Council'. These multiple networks were seen to bring strong benefits to DoArt, echoing the findings of Maurer and Ebers' (2006) study of biotechnology firms. In particular, they resulted in a differentiated and complementary composition of social capital at the firm level, which facilitated DoArt's successful embedding in the creative industries.

Symbolic capital was another essential resource Emily and her team leveraged during the establishment of DoArt. A common theme spanning interviews with all team members, as well as conversations with board members and network partners, was the high standing of Emily and her board of directors within the creative community. Several board members described Emily as having 'a significant reputation' and being 'a major player' within the creative industries. Similarly, both Cristie and Dorothy were aware of her reputation and identified the opportunity to work with her as a key reason for giving up secure employment to join DoArt. Furthermore, Emily was strategic in her recruitment of board members and drew upon her existing social and symbolic capital to attract directors who were 'influential within Scotland's creative scene' and 'able to plug gaps in our knowledge and to introduce us to people we 
need[ed] to know'. In this way, symbolic capital was used to generate legitimacy for DoArt. As Emily noted about one of the board members, 'If we are standing up and saying marketing things we need to have the credibility and what better credibility than the Professor of Marketing at one of the foremost universities in Scotland.'

Prior research, which compares the impact of forms of capital on new venture creation, has focused on the human and social capital of nascent entrepreneurs and indicates that, on balance, networks are more relevant than prior experiences (Davidsson and Honig, 2003; Elfring and Hulsink, 2007). While DoArt's team members considered social capital invaluable, they also stressed the importance of other resources, including cultural and symbolic capital, in embedding the firm within Scotland's creative industries. This is supported by prior studies, which reveal that familiarity with a location (cultural capital) and proximity to pre-existing relationships (social capital) play an important role in founders' decisions regarding where to establish their new ventures (Jack and Anderson, 2002; McKeever et al., 2015; Schutjens and Stam, 2003). We extend this perspective by arguing that symbolic capital can be similarly location-dependent, as symbolic resources lose their value outside of the contexts in which they are accepted and considered to be significant (Zott and Huy, 2007).

\section{Networking and embedding activities}

While the capital distribution of founding teams is instrumental in the initial positioning of nascent ventures, further activities are required to continue the embedding process post start-up (Hite, 2005). To date, few empirical studies have examined these ongoing activities. As such, there remain gaps in understanding regarding continuous embedding processes, particularly those relating to the use of networks as embedding mechanisms and the interactions needed to access network benefits (Ahuja et al., 2012; Hoang and Antoncic, 2003). This study therefore investigated the networking activities that DoArt's founder and team pursued to access resources and achieve embeddedness for the firm. 
Throughout DoArt's early development, it was apparent that everyone involved in the firm prioritised networking as a way of establishing connections, securing resources and, ultimately, achieving Emily's ambitions for the firm. From its inception, a commitment to networking had been championed by Emily, who explained that 'networking is in our DNA, if we cannot network, we cannot get the intelligence that gives us our USP [unique selling proposition]'. Over time, this commitment permeated to all employees, as illustrated by Jennifer, the firm's new Marketing Executive:

We do it [networking] quite a lot informally. Chances are, most weeks Emily is out there lobbying, attending meetings all the time. Between us, we are always attending training courses, events, even social events, just to raise our profile because we are quite a young company, so it is kind of on our agenda to make sure we are communicating as much as possible.

As her employees 'became more established, gained experience and built relationships', Emily's ambitions and intentions for DoArt evolved. She articulated that she wanted DoArt to be 'positioned as the agency that is associated with the Government's need to know anything about the impact of the arts on audiences, on people's lives, on audience behaviour'. To realise this intention, Emily undertook the strategic decision to widen the scope of DoArt's activities and increase their visibility by 'positioning DoArt across more markets' (Mairi). A key mechanism for further embedding DoArt within the Scottish creative sector was to extend the firm's portfolio of services by creating an industry-wide network and hosting dedicated networking events for industry members. Emily elaborated that, "when we got into it, people were looking for research and networking ... The market has plenty of training courses ... but what you cannot get is the glue in between'. Dorothy revealed that the strategic use of conferences hosted by DoArt helped realise Emily's goal of linking diverse stakeholder groups:

Our conference ... looked at how audience development is not just something for the arts but also for heritage, tourism, education and the commercial sectors. The main objective was to encourage communication and networking between these five sectors ... how all these are intertwined and how we should work [with them]. 
Team members also displayed careful planning of networking activities, manifested in clear demarcations of strategic, tactical and operational networking tasks allocated across staff according to their roles. This approach emerged as a key theme across several interviews, as illustrated by Miranda:

Emily does a lot of the communicating with a certain level of people, so she is always with the Chief Execs. ... Cristie and Dorothy are more the managerial and I am on the sort of officer/assistant level. It might not seem obvious to everyone but that is definitely the way it works in terms of our relations with certain people.

Cristie explained the reasoning behind these tactical behaviours:

Those at Chief Exec level only want to speak to Chief Execs - anyone lower and they say, 'Whatever!' Emily has to do communications quite often to Chief Execs because you have got to be really specifically targeted at what's hitting their buttons.

These comments support the interpretation that there was a clear division of networking activities within DoArt, with staff directing their interactions towards others holding similar positions in their firms (Hanna and Walsh, 2008). This tripartite approach was also observed at events organised by DoArt and during time spent at their premises. Interestingly, the demarcation of networking activities also represented one of the biggest challenges for Emily and the firm. As several network partners insisted on interacting with her alone, Emily was unable to delegate some operational responsibilities, which restricted her ability to 'think about the bigger picture'. This highlights that embeddedness in an industry can restrict the abilities of individuals to devolve or share responsibilities with team members (Maurer and Ebers, 2006).

One way that Emily found to deal with this issue was to ask Cristie and Dorothy to accompany her to meetings with influential partners. Initially, this practice required an even bigger commitment of resources, in the form of staff time, but it helped establish both employees as Emily's deputies. As Cristie explained: 'Since attending them [meetings], I suppose I am slightly better known in the circles, if you like, circles of influence, or circles of power'. Consequently, Emily's management team demanded an 
increase in remuneration, which constrained the firm's financial situation for a time. As part of their promotions, Cristie and Dorothy received new staff titles, which helped them fit in with the accepted norms and common hierarchies in the creative industry (De Clercq and Voronov, 2009) and permitted Emily to yield some of her responsibilities. This was one of the many outcomes of the networking and embedding activities we identified in this study, as discussed in the next section.

\section{Outcomes of networking and embedding activities}

We found that DoArt's approach to networking activities accrued a number of benefits (see Figure 1 and Appendix 1). Firstly, the variety of networks in which Emily and her team embedded the firm ensured that DoArt maintained a diverse mix of strong and weak ties at all levels (Davidsson and Honig, 2003; Granovetter, 1973). As suggested by Hite and Hesterly (2001), we recognised a shift in the type of ties that the firm developed over time. During the early stages, the venture relied almost exclusively on the strong ties of the founding team, which included family members and the board of directors. A growing number of weak ties, primarily consisting of clients, investors and members of professional and public bodies, were then added to the network (Elfring and Hulsink, 2007). This process greatly enhanced the social capital available to the firm. Similar to prior research (Birley et al., 1991; Larson, 1992; Sullivan and Marvel, 2011), we found that the most valuable resource these connections provided was access to information, which we consider a manifestation of economic capital, as it is a business asset that can readily be transformed into money. Accessible information ranged from competitors' recruitment decisions (operational) to software innovations that allowed tracking of audience attendance (tactical) and new government initiatives that encouraged audience development in areas such as music and dance (strategic).

By hosting dedicated networking events, DoArt was able to meet a range of actors from across Scotland's creative industries on a regular basis (Witt, 2004) and gain a brokerage position within the industry network. As Stam (2010) notes, prior experiences and capabilities (cultural capital) have a 
significant impact on the ability to gain a brokerage position through hosting and attending industry events. Emily benefitted in this regard from her active engagement in the creative community for over 20 years across a number of organisations and positions. The desire to engage in efficient networking was revealed during many interviews and was highlighted by Emily's comment that 'time is precious; if I am not getting something out of this then I am out because I have got about 300 million other things to do'. This was also reflected in DoArt's management of networking activities, which ensured that all members of staff were made aware of the need to strategically use interactions to 'raise the profile of DoArt' (Jennifer) and 'demonstrate value added' (Miranda).

A further benefit that DoArt accrued from its creation of an industry-wide network was the accumulation of symbolic capital. Building on research which highlights credibility as an important precursor to resource acquisition (Stringfellow et al., 2014; Zott and Huy, 2007), this study found that organising dedicated networking events is an effective mechanism for enhancing a firm's standing and legitimising its operations. Moreover, by achieving a leading position within the creative industries in Scotland, DoArt ensured that its chances for continued development and prosperity were markedly improved. Their newly formed connection to the Scottish Government, for example, provided DoArt with invitations to tender for large, creatively significant contracts and inclusion on approved tendering lists. Furthermore, by establishing a network that supported the development of the creative industries across Scotland, DoArt created considerable goodwill among industry members.

Through organising dedicated networking events, DoArt also affected the structure of the industry. As Emily and her team assumed the roles of brokers within their network, they were able to (re-)distribute valuable resources, such as the information they received from their clients, to advance their own interests (Birley et al., 1991; Stam, 2010). The more frequently DoArt's customers used its services and shared their knowledge, the stronger the firm's bargaining position and influence became within the creative industries. Over time, DoArt's team was able to gain a leading position within the 
sector and shape emerging connections between members (Vardaman et al., 2012). These findings contribute to an understanding of the dynamic between entrepreneurial agency and network structures (Hallen and Eisenhardt, 2012; Jack et al., 2010), by highlighting the effects of networking activities (agency) on industry structures.

Furthermore, we found that the power to influence the creative sector in Scotland extended to employees who joined DoArt over a year after its establishment, despite their lack of previous experience and reputation within the industry. New staff members were able to leverage the symbolic capital accumulated by the founding team and co-workers to build their own reputations and meet the strategic needs of the business (Wong and Boh, 2010). This reveals that, once a firm has gained legitimacy through the embedding process, the social and symbolic capital it possesses benefits all employees regardless of their prior embeddedness in the sector. As such, our study advances knowledge of the impact of legitimacy on new venture growth (Lounsbury and Glynn 2001; Zimmerman and Zeitz, 2002) and demonstrates that symbolic capital can be shared within an organisation in a similar manner as has been observed for social capital (Aarstad et al., 2010).

\section{Discussion}

Despite Aldrich and Kim's (2007: 148) insistence that 'a theory of entrepreneurship and social networks must encompass the entire life cycle of new organizations', there are few studies of the ongoing effects of embeddedness for firms, post start-up (Anderson et al., 2010; Hite and Hesterly, 2001; Jack et al., 2010). The longitudinal nature of this study enabled analysis of dedicated networking activities over time and provided valuable insights into the outcomes of these practices. It highlighted that embedding processes are not restricted to the period of new venture creation, but instead are ongoing and shaped by the evolving strategic intentions of a firm's founder and management team. 
Our findings address acknowledged research gaps concerning the impact of founding conditions and the implications of multiple, combined networks of founding teams on embedding processes (Jack and Anderson, 2002; Maurer and Ebers 2006; Witt, 2004). DoArt benefitted from the complementary experiences (cultural capital), various established networks (social capital) and prior reputations (symbolic capital) of the founding team, all of which combined to ease its entry into Scotland's creative industries. The empirical evidence presented suggests that a more holistic understanding of this phenomenon can be developed by extending the concept of embeddedness to include pre-embeddedness. We define pre-embeddedness as the sum of all cultural, social and symbolic capital that is possessed by founding team members prior to business start-up. Our study demonstrates that strong pre-embeddedness facilitates the favourable positioning of a nascent venture within its industry. As such, pre-embeddedness is a firm-level construct that provides an indicator for the potential success of a new business.

Our findings concerning DoArt's networking and embedding activities post start-up contribute to contemporary debates in the entrepreneurship literature. It is acknowledged that there are few rich descriptions of networking processes and interactions (Jack, 2010; Slotte-Kock and Coviello, 2010). The detailed descriptions presented in this article are valuable in this respect, as they add empirical weight to conceptual discussions of networking activities (Ahuja et al., 2012; De Clercq and Voronov, 2009; Nahapiet and Ghoshal, 1998). Our study also reveals that, as the ambitions for a firm evolve, staff may employ networking as a main instrument for achieving their strategic objectives (Miller et al., 2007). The demarcation of networking activities that we uncovered appears similarly strategic (Hanna and Walsh, 2008). Drawing from capital theory, we interpret this demarcation as a consequence of the varied amounts of cultural capital that team members possessed.

Furthermore, this article advances a deeper understanding of the use of networks as embedding mechanisms (Johannisson et al., 2002; Ozcan and Eisenhardt, 2009). While prior research has identified how certain network dimensions, such as tie strength and network centrality, can lead to particular 
benefits for large firms (Lechner et al., 2010), relevant knowledge of small firms is limited. This study highlights the importance of active engagement in networking activities for small firms (Obstfeld, 2005). By focussing on such activities, DoArt's founder and her employees were able to generate positive networking effects and to increase their firm's embeddedness in the industry. However, our study also reveals that embeddedness in an industry can restrict the ability of founders to devolve responsibilities to team members. As such, our findings demonstrate one of the challenges of embeddedness, which has not received adequate attention to date (Batjargal, 2003; Elfring and Hulsink, 2007). Furthermore, our study illustrates that, as a firm grows in size, the founder's importance to networking activities does not necessarily decrease (Maurer and Ebers, 2006).

Unlike other studies that highlight the importance of developing strong ties (Brüderl and Preisendörfer, 1998; Jack, 2005; Steier and Greenwood, 2000), we discovered that, following start-up, DoArt benefited more from its weak ties. We found that these ties primarily provided the firm with economic capital, in the form of operational, tactical and strategic information (Birley et al., 1991; Larson, 1992). In order to manage its large network of existing weak ties, DoArt decided to host networking events for the entire industry (Stam, 2010), which enabled them to reach out to large numbers of industry players simultaneously (Elfring and Hulsink, 2007; Steier and Greenwood, 2000). Our study reveals that, by hosting these events for a diversified group of participants, DoArt was able to gain a brokerage position within the industry network. In line with Stam (2010), we found that prior experiences and skills (cultural capital) allowed DoArt's team to effectively exploit this brokerage position by linking network members and redistributing resources to advance their own interests. While network research has emphasised the influence of structure over agency (Aldrich and Kim, 2007; Ozcan and Eisenhardt, 2009), this study offers an alternative perspective which highlights the effects of networking and embedding activities (agency) on industry structures. Furthermore, our study reveals that, by supporting the development of the whole industry, a firm can accumulate symbolic capital and create considerable 
goodwill among industry members. As Suchman (1995) points out, such 'dispositional perceptions act as a kind of capital reserve' (p. 596), which a firm can draw upon to sustain its standing in the community. As such, our study advances understanding of the utility of non-economic forms of capital (Pret et al., 2015), emphasising the ability to store symbolic capital and gradually deploy it over time.

\section{Conclusion and implications}

This study makes a number of contributions to knowledge concerning networking activities and their role in the process of embedding a small firm in its industrial context. While prior experience (cultural capital) and the networks of founding entrepreneurs (social capital) have been identified as enabling factors in new venture creation (Davidsson and Honig, 2003; Jayawarna et al. 2014), the effects of varied founding conditions on embedding processes remain unclear (Elfring and Hulsink, 2007). Furthermore, few studies examine the influence of the multiple, combined networks of founding teams on embedding processes (cf. Maurer and Ebers 2006; Witt 2004). This study advances understanding of these factors and of the use of networks as embedding mechanisms.

Firstly, findings regarding DoArt's founding conditions demonstrate the importance of preembeddedness (defined as the sum of all cultural, social and symbolic capital accessible to the founding team prior to business start-up). Secondly, this study highlights the value of cultural and symbolic capital, which has largely been overlooked (exceptions include: Lee and Shaw, 2016; Pret et al., 2015). Based on longitudinal observations of networking activities, this article provides new insights into the ways in which founders and their employees practise networking and access the benefits contained within their networks over time. In particular, we find the creation of industry networks and the hosting of networking events to be instrumental for further embedding a firm within its industrial context and for achieving its evolving strategic intentions. These activities are proven to be cost-effective mechanisms for managing a large network of primarily weak ties (Elfring and Hulsink, 2007; Steier and Greenwood, 2000). Our findings 
also illustrate that hosting networking events can help a small firm develop its reputation (symbolic capital) and thus substantiate its claims of legitimacy and attract new clients (economic/social capital).

This study reveals that the demarcation of networking activities according to existing hierarchies within the sector can help a new venture comply with industry norms (Hanna and Walsh, 2008). However, we also discover that this process can negatively affect a firm's owner by limiting her ability to delegate operational duties in favour of managerial activities. Furthermore, we show that high levels of pre-embeddedness and well-honed networking practices allow a new venture to gain a brokerage position within an industry network (Stam, 2010) and accrue advantages, including credibility and legitimacy

De Clercq and Voronov, 2009; Larson, 1992). These findings contribute to a deeper understanding of the role of entrepreneurial agency in the process of embedding a small firm in its industrial context (Elfring and Hulsink, 2007; Ozcan and Eisenhardt, 2009). Specifically, the empirical evidence presented highlights that networking activities (agency) can affect broader industry structures by linking members and (re-)distributing valuable resources among them. Thus, it is more accurate to conceive of embeddedness as a fluid process influenced by individual agency and evolving industry structures rather than a fixed state of being.

It is important to note that the case study approach of this study inhibits generalisability (Cope, 2011; Lewis, 2015). While it is likely that the findings discussed will reflect the experiences of other small, young firms in the creative industries, their broader application cannot be assumed. More structured research and investigations in other contexts are therefore needed to confirm our findings. A second limitation relates to the selection of DoArt as a special case. We found that DoArt possessed high levels of pre-embeddedness and that all members of staff were committed to networking as a key business practice. Acknowledging that 'not all emerging firms are equally endowed in terms of initial network connections and [that] these differences matter' (Hite and Hesterly, 2001: 283), we recommend that future studies explore embedding as experienced by firms with less favourable starting conditions. 
Such research is likely to reveal further insights into the role of entrepreneurial agency and its impact on the direction, speed and extent of embedding processes.

Furthermore, it would be interesting to investigate the degree to which new members of staff can acquire the reputation of a firm and its employees. Our study found that symbolic capital could be shared among staff members in a similar fashion as social capital (Aarstad et al., 2010). Thus, we propose that future research examine such capital sharing practices in more detail. It should also be noted that, as our case firm remained micro-sized (employing less than 10 people), the influence of the founder was not markedly diluted over time. However, as Maurer and Ebers (2006) suggest, as a firm grows in size, it can become challenging for founders to ensure that multiple networking activities remain well integrated. Accordingly, we suggest that future studies investigate how firms deal with the networking difficulties that can arise as a consequence of sustained growth.

It has been argued that a limitation of network research in entrepreneurship is the inability to offer practical advice to entrepreneurs (Witt, 2004). The findings of this study contribute in this respect by suggesting that, when establishing their firms, entrepreneurs will benefit from locating new businesses within industries and locations in which they possess a large degree of pre-embeddedness in the form of cultural, social and symbolic capital. To increase the chances of venture success, entrepreneurs should also seek to recruit founding team members according to the amounts of non-financial capital available to them. Furthermore, our findings highlight the positive effects of networking activities. To date, networking advice has concentrated on recommending that entrepreneurs carefully consider which networks they join and how much time they invest in networking activities. We suggest that entrepreneurs and their team members consider networking as a business practice that should be aligned with the evolving strategic intentions of the firm. Finally, we propose that founders and their teams will benefit from informing themselves about industrial and regional norms and from ensuring that their networking activities conform to these conventions. If applied correctly, networking can be an effective means for embedding a firm and developing it as a credible and legitimate player within its industrial context. 


\section{Funding}

This research received no specific grant from any funding agency in the public, commercial, or not-forprofit sectors.

\section{Notes}

1. While networking has been variously defined, we build on Larson and Starr's (1993) concept and define networking as a process of exploring, selecting and using dyadic ties. Drawing on Jack (2005), we acknowledge that networks become more complex over time and that effective networking requires a process of embedding.

2. Granovetter (1973) differentiates between strong and weak ties. 'Strong ties [are] relations entrepreneurs can "count on.” By contrast, weak ties are superficial or casual, and people typically have little emotional investment in them' (Dubini and Aldrich, 1991: 307).

3. A 'structural hole [is] a gap in the social network between two actors that can be spanned or is spanned by another actor' (Kilduff and Brass, 2010: 357). Burt (1992) argues that an effective network has many structural holes and thus links the entrepreneur to a diverse range of nonoverlapping clusters of people (Steier and Greenwood, 2000).

4. "The "bridging view" of social capital argues that entrepreneurs with large, diverse, and weakly connected personal networks identify more novel opportunities but face difficulties assembling resources to exploit them ... [while] the "bonding view" of social capital maintains that entrepreneurs with small, cohesive personal networks composed of strong ties can more effectively mobilize resources around new projects but lack access to fresh ideas' (Stam et al., 2014: 155).

5. We were only able to conduct one interview with Miranda. 


\section{References}

Aarstad J, Haugland SA and Greve A (2010) Performance Spillover Effects in Entrepreneurial Networks:

Assessing a Dyadic Theory of Social Capital. Entrepreneurship Theory and Practice 34(5): $1003-1019$.

Adler PS and Kwon S-W (2002) Social Capital: Prospects for a new Concept. Academy of Management Review 27(1): 17-40.

Ahuja G, Soda G and Zaheer A (2012) The Genesis and Dynamics of Organizational Networks. Organization Science 23(2): 434-448.

Al-Dajani H, Carter S, Shaw E and Marlow S (2015) Entrepreneurship among the Displaced and Dispossessed: Exploring the Limits of Emancipatory Entrepreneuring. British Journal of Management 26(4): 713-730.

Aldrich HE and Kim PH (2007) Small worlds, infinite possibilities? How social networks affect entrepreneurial team formation and search. Strategic Entrepreneurship Journal 1(1-2): 147-165.

Aldrich HE and Zimmer C (1986) Entrepreneurship through Social Networks. In: Sexton DL and Smilor RW (eds) The Art and Science of Entrepreneurship. Cambridge, MA: Ballinger, pp.3-23.

Anderson AR, Drakopoulou Dodd S and Jack SL (2010) Network practices and entrepreneurial growth. Scandinavian Journal of Management 26(2): 121-133.

Antcliff V, Saundry R and Stuart M (2007) Networks and social capital in the UK television industry: The weakness of weak ties. Human Relations 60(2): 371-393.

Batjargal B (2003) Social Capital and Entrepreneurial Performance in Russia: A Longitudinal Study. Organization Studies 24(4): 535-556.

Becker, GS (1964) Human capital: A theoretical analysis with special reference to education. New York, NY: National Bureau for Economic Research.

Berglund H (2015) Between cognition and discourse: phenomenology and the study of entrepreneurship. International Journal of Entrepreneurial Behavior \& Research 21(3): 472-488. 
Birley S (1985) The role of networks in the entrepreneurial process. Journal of Business Venturing 1(1): $107-117$.

Birley S, Cromie S and Myers A (1991) Entrepreneurial Networks: Their Emergence in Ireland and Overseas. International Small Business Journal 9(4): 56-74.

Bourdieu P (1977) Outline of a Theory of Practice. Cambridge, MA: Cambridge University Press.

Bourdieu P (1986) The Forms of Capital. In: Richardson JG (ed.) The handbook of theory and research for the sociology of education. New York, NY: Greenwood Press, pp.241-258.

Brüderl J and Preisendörfer P (1998) Network support and the success of newly founded businesses. Small Business Economics 10(3): 213-225.

Burt RS (1992) Structural holes: the social structure of competition. Cambridge, MA: Harvard University Press.

Casson M and Della Giusta M (2007) Entrepreneurship and Social Capital: Analysing the Impact of Social Networks on Entrepreneurial Activity from a Rational Action Perspective. International Small Business Journal 25(3): 220-244.

Chalmers DM and Shaw E (2015) The endogenous construction of entrepreneurial contexts: A practicebased perspective. International Small Business Journal. Epub ahead of print 21 September. DOI: $10.1177 / 0266242615589768$.

Chetty SK, Partanen J, Rasmussen ES and Servais P (2014) Contextualising case studies in entrepreneurship: A tandem approach to conducting a longitudinal cross-country case study. International Small Business Journal 32 (7): 818-829.

Cope J (2005) Researching Entrepreneurship through Phenomenological Inquiry: Philosophical and Methodological Issues. International Small Business Journal 23(2): 163-189.

Cope J (2011) Entrepreneurial learning from failure: An interpretative phenomenological analysis. Journal of Business Venturing 26(6): 604-623.

Drakopoulou Dodd S (2014) Roots radical - place, power and practice in punk entrepreneurship. Entrepreneurship and Regional Development 26(1-2): 165-205. 
Drakopoulou Dodd S, Pret T and Shaw E (2016) Advancing Understanding of Entrepreneurial Embeddedness: Forms of Capital, Social Contexts and Time. In: Welter F and Gartner WB (eds) A Research Agenda for Entrepreneurship and Context. Cheltenham: Edward Elgar, pp. 120-133.

Davidsson P and Honig B (2003) The role of social and human capital among nascent entrepreneurs. Journal of Business Venturing 18(3): 301-331.

De Clercq D and Voronov M (2009) Toward a Practice Perspective of Entrepreneurship: Entrepreneurial Legitimacy as Habitus. International Small Business Journal 27(4): 395-419.

Department for Culture, Media \& Sport (2016) Creative Industries Economic Estimates January 2016 (Report). London: Department for Culture, Media \& Sport.

Dubini P and Aldrich H (1991) Personal and extended networks are central to the entrepreneurial process. Journal of Business Venturing 6(5): 305-313.

Edmondson AC and McManus SE (2007) Methodological Fit in Management Field Research. Academy of Management Review 32(4): 1155-1179.

Elfring T and Hulsink W (2007) Networking by Entrepreneurs: Patterns of Tie-Formation in Emerging Organizations. Organization Studies 28(12): 1849-1872.

Gartner WB (2007) Entrepreneurial narrative and a science of the imagination. Journal of Business Venturing, 22(5): 613-627.

Giddens A (1984) Constitution of society: outline of the theory of structuration. Cambridge: Polity Press. Granovetter M (1973) The Strength of Weak Ties. American Journal of Sociology 78(6): 1360-1380.

Granovetter M (1985) Economic Action and Social Structure: The Problem of Embeddedness. American Journal of Sociology 91(3): 481-510.

Greve A and Salaff JW (2003) Social Networks and Entrepreneurship. Entrepreneurship Theory and Practice 28(1): 1-22. 
Grossman EB, Yli-Renko H and Janakiraman R (2012) Resource Search, Interpersonal Similarity, and Network Tie Valuation in Nascent Entrepreneurs' Emerging Networks. Journal of Management 38 (6): $1760-1787$.

Hallen BL and Eisenhardt KM (2012) Catalyzing Strategies and Efficient Tie Formation: How Entrepreneurial Firms Obtain Investment Ties. Academy of Management Journal 55(1): 35-70.

Hanna V and Walsh K (2008) Interfirm Cooperation among Small Manufacturing Firms. International Small Business Journal 26 (3): 299-321.

Hite JM (2005) Evolutionary Processes and Paths of Relationally Embedded Network Ties in Emerging Entrepreneurial Firms. Entrepreneurship Theory and Practice 29(1): 113-144.

Hite JM and Hesterly WS (2001) The evolution of firm networks: From emergence to early growth of the firm. Strategic Management Journal 22(3): 275-286.

Hoang H and Antoncic B (2003) Network-based research in entrepreneurship: A critical review. Journal of Business Venturing 18(2): 165-187.

Jack SL (2005) The Role, Use and Activation of Strong and Weak Network Ties: A Qualitative Analysis. Journal of Management Studies 42(6): 1233-1259.

Jack SL (2010) Approaches to studying networks: Implications and outcomes. Journal of Business Venturing 25(1): 120-137.

Jack SL and Anderson AR (2002) The effects of embeddedness on the entrepreneurial process. Journal of Business Venturing 17(5): 467-487.

Jack SL, Moult S, Anderson AR and Drakopoulou Dodd S (2010) An entrepreneurial network evolving: Patterns of change. International Small Business Journal 28(4): 315-337.

Jayawarna D, Jones O and Macpherson A (2014) Entrepreneurial potential: The role of human and cultural capitals. International Small Business Journal 32(8): 918-943.

Johannisson B, Ramírez-Pasillas M and Karlsson G (2002) The institutional embeddedness of local inter-firm networks: a leverage for business creation. Entrepreneurship \& Regional Development 14(4): 297-315. 
Karataş-Özkan M (2011) Understanding relational qualities of entrepreneurial learning: Towards a multilayered approach. Entrepreneurship and Regional Development 23(9-10): 877-906.

Karataş-Özkan M and Chell E (2010) Nascent Entrepreneurship and Learning. Cheltenham: Edward Elgar.

Kilduff M and Brass DJ (2010) Organizational Social Network Research: Core Ideas and Key Debates. Academy of Management Annals 4(1): 317-357.

Keating A, Geiger S and McLoughlin D (2014) Riding the Practice Waves: Social Resourcing Practices During New Venture Development. Entrepreneurship Theory and Practice 38(5): 1207-1235.

Korsgaard S, Ferguson R and Gaddefors J (2015) The best of both worlds: how rural entrepreneurs use placial embeddedness and strategic networks to create opportunities. Entrepreneurship and Regional Development 27(9-10): 574-598.

Lam W and Harker MJ (2015) Marketing and entrepreneurship: An integrated view from the entrepreneur's perspective. International Small Business Journal 33(3): 321-348.

Larson A (1992) Network dyads in entrepreneurial settings: A study of the governance of exchange processes. Administrative Science Quarterly 37(1): 76-104.

Larson A and Starr JA (1993) A Network Model of Organization Formation. Entrepreneurship Theory and Practice 17(2): 5-15.

Lechner C and Dowling M (2003) Firm networks: external relationships as sources for the growth and competitiveness of entrepreneurial firms. Entrepreneurship and Regional Development 15(1): 1-26.

Lechner C, Frankenberger K and Floyd SW (2010) Task Contingencies in the Curvilinear Relationships Between Intergroup Networks and Initiative Performance. Academy of Management Journal 53(4): $865-889$.

Lee R and Jones O (2008) Networks, Communication and Learning during Business Start-up: The Creation of Cognitive Social Capital. International Small Business Journal 26(5): 559-594. 
Lee R and Shaw E (2016) Bourdieu's non-material forms of capital: Implications for start-up policy. Environment and Planning C: Government and Policy. Epub ahead of print 27 April 2016. DOI: $10.1177 / 0263774 \times 16638850$.

Leitch CM, Hill FM and Harrison RT (2010) The Philosophy and Practice of Interpretivist Research in Entrepreneurship: Quality, Validation, and Trust. Organizational Research Methods 13(1): 67-84. Lewis KV (2015) Enacting Entrepreneurship and Leadership: A Longitudinal Exploration of Gendered Identity Work. Journal of Small Business Management 53(3): 662-682.

Lincoln YS and Guba EG (1985) Naturalistic inquiry. Newbury Park, CA: Sage.

Lounsbury M and Glynn MA (2001) Cultural Entrepreneurship: Stories, Legitimacy, and the Acquisition of Resources. Strategic Management Journal 22(6/7): 545-564.

McAdam M, McAdam R, Dunn A and McCall C (2014) Development of small and medium-sized enterprise horizontal innovation networks: UK agri-food sector study. International Small Business Journal 32(7): 830-853.

McKeever E, Jack SL and Anderson AR (2015) Embedded entrepreneurship in the creative reconstruction of place. Journal of Business Venturing 30(1): 50-65.

McLeod C, O'Donohoe S and Townley B (2009) The elephant in the room? Class and creative careers in British advertising agencies. Human Relations 62(7): 1011-1039.

McPherson M, Smith-Lovin L and Cook JM (2001) Birds of a Feather: Homophily in Social Networks. Annual Review of Sociology 27(1): 415-444.

Manning S (2010) The strategic formation of project networks: A relational practice perspective. Human Relations 63(4): 551-573

Marlow S and McAdam M (2015) Incubation or Induction? Gendered Identity Work in the Context of Technology Business Incubation. Entrepreneurship Theory and Practice 39(4): 791-816.

Maurer I and Ebers M (2006) Dynamics of Social Capital and Their Performance Implications: Lessons from Biotechnology Start-ups. Administrative Science Quarterly 51(2): 262-292. 
Miller NJ, Besser T and Malshe A (2007) Strategic Networking among Small Businesses in Small US Communities. International Small Business Journal 25(6): 631-665.

Mitchell JC (1969) The Concept and Use of Social Networks. In: Mitchell JC (ed.) Social Networks in Urban Situations: Analyses of Personal Relationships in Central African Towns. Manchester: Manchester University Press, pp.1-50.

Nahapiet J and Ghoshal S (1998) Social Capital, Intellectual Capital, and the Organizational Advantage. Academy of Management Review 23 (2): 242-266.

Obstfeld D (2005) Social Networks, the Tertius Iungens Orientation, and Involvement in Innovation. Administrative Science Quarterly 50(1): 100-130.

Ozcan P and Eisenhardt KM (2009) Origin of alliance portfolios: entrepreneurs, network strategies, and firm performance. Academy of Management Journal 52(2): 246-279.

Parkinson C, Howorth C and Southern A (2016) The crafting of an (un)enterprising community: Context and the social practice of talk. International Small Business Journal. Epub ahead of print 15 January 2016. DOI: 10.1177/0266242615621123.

Patton MQ (2002) Qualitative research and evaluation methods (3rd edn). Thousand Oaks, CA: Sage.

Phillips N, Tracey P and Karra N (2013) Building entrepreneurial tie portfolios through strategic homophily: The role of narrative identity work in venture creation and early growth. Journal of Business Venturing 28(1): 134-150.

Pret T, Shaw E and Drakopoulou Dodd S (2015) Painting the Full Picture: The Conversion of Economic, Cultural, Social and Symbolic Capital. International Small Business Journal. Epub ahead of print 27 July 2015. DOI: 10.1177/0266242615595450.

Ram M, Theodorakopoulos N and Jones T (2008) Forms of capital, mixed embeddedness and Somali enterprise. Work, Employment \& Society 22(3): 427-446.

Ruef M, Aldrich HE and Carter NM (2003) The Structure of Founding Teams: Homophily, Strong Ties, and Isolation among U.S. Entrepreneurs. American Sociological Review 68(2): 195-222. 
Salancik GR (1995) Wanted: A good networking theory of organization. Administrative Science Quarterly 40(2): 345-349.

Schatzki T (2002) The Site of the Social: A Philosophical Account of Social Life and Change. University Park, PA: The University of Pennsylvania State University Press.

Schutjens V and Stam E (2003) The Evolution and Nature of Young Firm Networks: a longitudinal Perspective. Small Business Economics 21(2): 115-134.

Shaw E (2006) Small Firm Networking: An Insight into Contents and Motivating Factors. International Small Business Journal 24(1): 5-29.

Shaw E, Gordon J, Harvey C and Maclean M (2013) Exploring contemporary entrepreneurial philanthropy. International Small Business Journal 31(5): 580-599.

Silverman D (2000) Doing Qualitative Research. London: Sage.

Slotte-Kock S and Coviello N (2010) Entrepreneurship Research on Network Processes: A Review and Ways Forward. Entrepreneurship Theory and Practice 34(1): 31-57.

Spigel B (2016) Bourdieu, culture, and the economic geography of practice: entrepreneurial mentorship in Ottawa and Waterloo, Canada. Journal of Economic Geography. Epub ahead of print 17 July 2016. DOI: $10.1093 /$ jeg/lbw019.

Stake R (2000) Case Studies. In: Denzin NK and Lincoln YS (eds) Handbook of Qualitative Research (2nd edn). Thousand Oaks, CA: Sage, pp.435-454.

Stam W (2010) Industry Event Participation and Network Brokerage among Entrepreneurial Ventures. Journal of Management Studies 47(4): 625-653.

Stam W, Arzlanian S and Elfring T (2014) Social capital of entrepreneurs and small firm performance: A metaanalysis of contextual and methodological moderators. Journal of Business Venturing 29(1): 152-173.

Steier L and Greenwood R (2000) Entrepreneurship and the Evolution of Angel Financial Networks. Organization Studies 21(1): 163-192. 
Steyaert C and Landström H (2011) Enacting entrepreneurship research in pioneering, provocative and participative way: On the work of Bengt Johannisson. Small Business Economics 36(2): 123-134.

Stringfellow L, Shaw E and Maclean M (2014) Apostasy versus legitimacy: Relational dynamics and routes to resource acquisition in entrepreneurial ventures. International Small Business Journal 32(5): 571-592.

Stringfellow L and Maclean M (2014) 'Space of Possibles'? Legitimacy, Industry Maturity, and Organizational Foresight. Strategic Change 23(3-4): 171-183.

Suchman MC (1995) Managing Legitimacy: Strategic and Institutional Approaches. Academy of Management Review 20(3): 571-610.

Suddaby R, Bruton GD and Si SX (2015) Entrepreneurship through a qualitative lens: Insights on the construction and/or discovery of entrepreneurial opportunity. Journal of Business Venturing 30(1): 1-10.

Sullivan DM and Ford CM (2014) How Entrepreneurs Use Networks to Address Changing Resource Requirements During Early Venture Development. Entrepreneurship Theory and Practice 38(3): $551-574$.

Sullivan D and Marvel M (2011) How Entrepreneurs' Knowledge and Network Ties Relate to the Number of Employees in New SMEs. Journal of Small Business Management 49(2): 185-206.

Townley B, Beech N and McKinlay A (2009) Managing in the creative industries: Managing the motley crew. Human Relations 62 (7): 939-962.

Terjesen S and Elam AB (2009) Transnational Entrepreneurs' Venture Internationalization Strategies: A Practice Theory Approach. Entrepreneurship Theory and Practice 33(5): 1093-1120.

United Nations Development Programme (2013) Creative Economy Report 2013 Special Edition (Report). New York: United Nations Development Programme.

Uzzi B (1997) Social Structure and Competition in Interfirm Networks: The Paradox of Embeddedness. Administrative Science Quarterly 42(1): 35-67. 
Uzzi B and Gillespie JJ (2002) Knowledge spillover in corporate financing networks: embeddedness and the firm's debt performance. Strategic Management Journal 23(7): 595-618.

Vardaman JM, Amis JM, Dyson BP, Wright PM and Van de Graaff Randolph R (2012) Interpreting change as controllable: The role of network centrality and self-efficacy. Human Relations 65(7): 835-859.

Vincent S (2005) Really dealing: a critical perspective on inter-organizational exchange networks. Work, Employment \& Society 19(1): 47-65.

Welter F (2011) Contextualizing Entrepreneurship-Conceptual Challenges and Ways Forward. Entrepreneurship Theory and Practice 35(1): 165-184.

Wilson J, Arshed N, Shaw E and Pret T (2016) Expanding the Domain of Festival Research: A Review and Research Agenda. International Journal of Management Reviews. Epub ahead of print 15 February. DOI: 10.1111/ijmr.12093.

Witt P (2004) Entrepreneurs' networks and the success of start-ups. Entrepreneurship and Regional Development 16(5): 391-412.

Wong S-S and Boh WF (2010) Leveraging the Ties of Others to Build a Reputation for Trustworthiness among their Peers. Academy of Management Journal 53(1): 129-148.

Zahra SA, Wright $M$ and Abdelgawad SG (2014) Contextualization and the advancement of entrepreneurship research. International Small Business Journal 32(5): 479-500.

Zimmerman MA and Zeitz GJ (2002) Beyond Survival: Achieving New Venture Growth by Building Legitimacy. Academy of Management Review 27(3): 414-431.

Zott C and Huy QN (2007) How Entrepreneurs Use Symbolic Management to Acquire Resources. Administrative Science Quarterly 52(1): 70-105.

Zou H, Chen X, Lam LWR and Liu X (2016) Psychological capital and conflict management in the entrepreneur-venture capitalist relationship in China: The entrepreneur perspective. International Small Business Journal 34(4): 446-467. 
Table 1 Research Participants

\begin{tabular}{|l|l|l|l|l|}
\hline Name & Position & $\begin{array}{l}\text { Start of } \\
\text { Employment }\end{array}$ & $\begin{array}{l}\text { Relevant } \\
\text { Experience }\end{array}$ & Responsibilities \\
\hline Emily & $\begin{array}{l}\text { Founder, } \\
\text { Managing } \\
\text { Director }\end{array}$ & Before start-up & $>20$ years & $\begin{array}{l}\text { Develops strategic objectives; public face of } \\
\text { DoArt; liaises with stakeholders; lobbies } \\
\text { government. }\end{array}$ \\
\hline Cristie & $\begin{array}{l}\text { Head of } \\
\text { Research }\end{array}$ & Before start-up & 5 years & $\begin{array}{l}\text { Manages research projects; liaises with } \\
\text { clients. }\end{array}$ \\
\hline Dorothy & $\begin{array}{l}\text { Head of } \\
\text { Audience } \\
\text { Development }\end{array}$ & Before start-up & 12 years & $\begin{array}{l}\text { Uses research findings to inform audience } \\
\text { development strategies; liaises with clients. }\end{array}$ \\
\hline Jennifer & $\begin{array}{l}\text { Marketing } \\
\text { Executive }\end{array}$ & After 14 months & none & $\begin{array}{l}\text { Assists Head of Audience Development with } \\
\text { collecting intelligence and devising strategies. }\end{array}$ \\
\hline Miranda & $\begin{array}{l}\text { Marketing } \\
\text { Executive }\end{array}$ & After 17 months & none & $\begin{array}{l}\text { Assists Head of Audience Development with } \\
\text { collecting intelligence and devising strategies. }\end{array}$ \\
\hline Mairi & $\begin{array}{l}\text { Secretary } \\
\text { After } 14 \text { months }\end{array}$ & none & $\begin{array}{l}\text { Performs secretarial duties: answering } \\
\text { phones, photocopying, general helping out. }\end{array}$ \\
\hline
\end{tabular}

Figure 1 The Process of Embedding a Small Firm in its Industrial Context

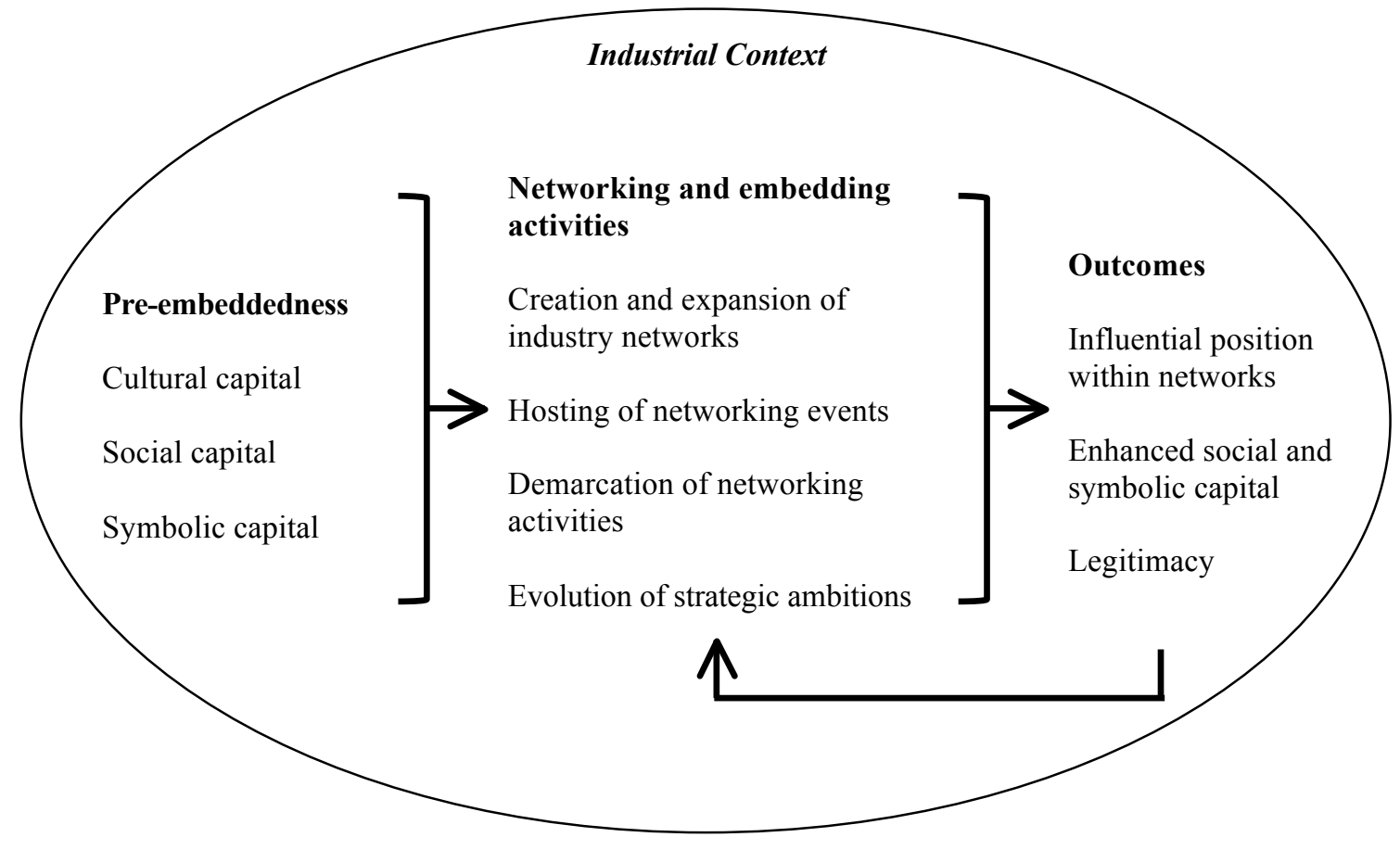


Appendix 1. Data Coding

\begin{tabular}{|c|c|c|}
\hline Examples from raw data & $\begin{array}{l}1^{\text {st }} \text { order } \\
\text { concepts }\end{array}$ & $\begin{array}{l}2^{\text {nd }} \text { order } \\
\text { themes }\end{array}$ \\
\hline \multicolumn{3}{|l|}{ Aggregate theoretical dimension: Pre-embeddedness } \\
\hline $\begin{array}{l}\text { 'I started as a marketing executive ... after about two years, I was working more of a research executive [role] } \ldots \\
\text { and then the Research Manager left and I was asked if I wanted the position, so I took it'. (Cristie) }\end{array}$ & $\begin{array}{l}\text { Work } \\
\text { Experience }\end{array}$ & \multirow{3}{*}{$\begin{array}{l}\text { Cultural } \\
\text { Capital }\end{array}$} \\
\hline $\begin{array}{l}\text { 'The advanced marketing course ... I was on two of those - they were week-long, residential courses. I basically just } \\
\text { did any training that I could get my hands on'. (Emily) }\end{array}$ & $\begin{array}{l}\text { Education and } \\
\text { Training }\end{array}$ & \\
\hline $\begin{array}{l}\text { 'Because I have got an arts background, I have got much more of an appreciation of where people are sitting on the } \\
\text { food chain and it makes it easier for people to talk to me, as well'. (Dorothy) }\end{array}$ & Habituation & \\
\hline $\begin{array}{l}\text { 'The great thing about [friend] is his contact book, and also his point of view. He has got a really engaging and very } \\
\text { kind of ... Presbyterian [giving] attitude'. (Emily) }\end{array}$ & Friends & \multirow{4}{*}{$\begin{array}{l}\text { Social } \\
\text { Capital }\end{array}$} \\
\hline $\begin{array}{l}\text { Observation: At a networking event, we observed Cristie being introduced to several potential clients for DoArt by a } \\
\text { contact she retained from her previous job as a Research Manager. }\end{array}$ & Contacts & \\
\hline $\begin{array}{l}\text { 'The key thing in terms of the fundraising was [supporter] ... one of the richest "old boys" of Glasgow ... He then } \\
\text { just phones his pals, I mean ... "passionately engages" his pals [to help out]'. (Emily) }\end{array}$ & Supporters & \\
\hline $\begin{array}{l}\text { 'I had heard of her [Emily] ... but I did not move in the same circles, she was more Council and I was more non- } \\
\text { Council'. (Dorothy) }\end{array}$ & $\begin{array}{l}\text { Distinct } \\
\text { Networks }\end{array}$ & \\
\hline $\begin{array}{l}\text { '[I was] Head of Marketing ... for what was a combined department of the sport, leisure, museums, galleries, } \\
\text { printworks, graphic division, sports centres, ... ticket centre, so it was quite a big job'. (Emily) }\end{array}$ & $\begin{array}{l}\text { Personal } \\
\text { Esteem }\end{array}$ & \multirow{3}{*}{$\begin{array}{l}\text { Symbolic } \\
\text { Capital }\end{array}$} \\
\hline $\begin{array}{l}\text { Observation: At a drinks reception, we observed Emily discussing her established reputation within the Scottish } \\
\text { creative industries with potential clients to convince them of DoArt's potential. }\end{array}$ & $\begin{array}{l}\text { Prior } \\
\text { Reputation }\end{array}$ & \\
\hline $\begin{array}{l}\text { Observation: At the launch of an event, we witnessed the leader of an established art organisation praise the work that } \\
\text { Cristie had done for him in the past and vouch for her abilities to produce high quality work. }\end{array}$ & Referees & \\
\hline \multicolumn{3}{|l|}{ Aggregate theoretical dimension: Networking and Embedding Activities } \\
\hline $\begin{array}{l}\text { 'Not a lot of people outside ... the small arts sector know who we are, and that is something that Emily is quite keen } \\
\text { to develop and networking is definitely the way to do it'. (Cristie) }\end{array}$ & $\begin{array}{l}\text { Brand Identity } \\
\text { Building }\end{array}$ & \multirow{2}{*}{$\begin{array}{l}\text { Industry } \\
\text { Network } \\
\text { Creation }\end{array}$} \\
\hline $\begin{array}{l}\text { 'There are } 15 \text { other audience development agencies south of the border ... part of what is called [network } \\
\text { organisation], ... so you kind of have to network there, but I find it quite challenging because it is costly [and] it } \\
\text { takes you a lot of time out of the office. (Emily) }\end{array}$ & $\begin{array}{l}\text { Alliance } \\
\text { Formation }\end{array}$ & \\
\hline
\end{tabular}




\begin{tabular}{|c|c|c|}
\hline $\begin{array}{l}\text { 'Networking from a very informal perspective is, I suppose, sending emails and having a quick chat with [member] } \\
\text { to support him ... and a shoulder to cry on if you like. And there is the more formalised [side] - the research } \\
\text { meetings and everything else'. (Jennifer) }\end{array}$ & $\begin{array}{l}\text { Support } \\
\text { Provision }\end{array}$ & \\
\hline $\begin{array}{l}\text { 'We just try to ensure that there is always networking going on ... so we are kind of encouraging online networking, } \\
\text { but predominantly I would say that it is events and showing our face'. (Mairi) }\end{array}$ & $\begin{array}{l}\text { Continuous } \\
\text { Engagement }\end{array}$ & \multirow{3}{*}{$\begin{array}{l}\text { Industry } \\
\text { Network } \\
\text { Expansion }\end{array}$} \\
\hline $\begin{array}{l}\text { 'When I was at the ... meeting with all the other arts organisations, it was a networking opportunity ... an } \\
\text { opportunity to promote DoArt' (Miranda) }\end{array}$ & $\begin{array}{l}\text { Service } \\
\text { Promotion }\end{array}$ & \\
\hline $\begin{array}{l}\text { 'The economic summit they have every year, it is a networking meeting ... I find elements of it really uncomfortable } \\
\text { but when it is genuine, I ... do create genuine relationships'. (Emily) }\end{array}$ & $\begin{array}{l}\text { Relationship } \\
\text { Development }\end{array}$ & \\
\hline $\begin{array}{l}\text { 'We have been networking and getting people together at different events, like our conference, everyone knows each } \\
\text { other better ... there is a bit more camaraderie now and support'. (Dorothy) }\end{array}$ & $\begin{array}{l}\text { Fellowship } \\
\text { Building }\end{array}$ & \multirow{4}{*}{$\begin{array}{l}\text { Hosting of } \\
\text { Networking } \\
\text { Events }\end{array}$} \\
\hline $\begin{array}{l}\text { 'All the sort of imagery and promotion that we had for it [event] showed how these sectors are intertwined and how } \\
\text { they should work together ... arts, heritage, education, tourism and commercial'. (Jennifer) }\end{array}$ & $\begin{array}{l}\text { Intermediary } \\
\text { Function }\end{array}$ & \\
\hline $\begin{array}{l}\text { 'I don't think there are a lot of companies that actively seek as many opportunities ... to offer networking ... [to] } \\
\text { members through holding social events, training, conferences'. (Mairi) }\end{array}$ & $\begin{array}{l}\text { Portfolio } \\
\text { Creation }\end{array}$ & \\
\hline $\begin{array}{l}\text { Annual Report: 'DoArt aims ... to develop and sustain audience growth for the arts ... [by helping] organizations } \\
\text { work together'. }\end{array}$ & $\begin{array}{l}\text { Audience } \\
\text { Development }\end{array}$ & \\
\hline $\begin{array}{l}\text { 'I make a decision ... who needs to be there [networking event], so three of the team are there in a development role } \\
\text { and two are there schmoosing'. (Emily) }\end{array}$ & $\begin{array}{l}\text { Delegation of } \\
\text { Responsibilities }\end{array}$ & \multirow{3}{*}{$\begin{array}{l}\text { Demarcation } \\
\text { of Networking } \\
\text { Activities }\end{array}$} \\
\hline $\begin{array}{l}\text { 'He is the Head of Sales and Marketing for two theatres ... I would be delighted to meet with him ... and would not } \\
\text { feel threatened ... I couldn't say the same for ... the Chief Exec, though'. (Cristie) }\end{array}$ & $\begin{array}{l}\text { Social } \\
\text { Stratification }\end{array}$ & \\
\hline $\begin{array}{l}\text { 'Emily gets most of the invites because ... organisations are not meant to be handing out free tickets all the time. So } \\
\text { it is from the top down only'. (Mairi) }\end{array}$ & $\begin{array}{l}\text { Preferential } \\
\text { Treatment }\end{array}$ & \\
\hline $\begin{array}{l}\text { 'The website is about to be redeveloped because ... we want to use our website as a central point for communication } \\
\text { for the wider network ... which will help when we start talking about lobbying'. (Dorothy) }\end{array}$ & $\begin{array}{l}\text { Capacity } \\
\text { Expansion }\end{array}$ & \multirow{4}{*}{$\begin{array}{l}\text { Evolution of } \\
\text { Strategic } \\
\text { Ambitions }\end{array}$} \\
\hline $\begin{array}{l}\text { 'You have got experienced staff, you are building relationships and ... what I have got to do [now] ... is develop new } \\
\text { products which we can identify with or be identified with'. (Emily) }\end{array}$ & \begin{tabular}{|l} 
Service \\
Development
\end{tabular} & \\
\hline $\begin{array}{l}\text { AGM Minutes: '[Our vision is] to become experts in cultural research, project management and innovation, with the } \\
\text { aim of brokering relationships ... targeting potential new collaborations and stimulating audience growth'. }\end{array}$ & $\begin{array}{l}\text { Strategic } \\
\text { Development }\end{array}$ & \\
\hline $\begin{array}{l}\text { Annual Report: 'DoArt's challenge ... [is] to harness a combined approach, shared knowledge, learning from one } \\
\text { another, promoting collective impact and change'. }\end{array}$ & $\begin{array}{l}\text { Impact } \\
\text { Maximisation }\end{array}$ & \\
\hline
\end{tabular}




\begin{tabular}{|c|c|c|}
\hline $\begin{array}{l}\text { 'They won't give you the mailing list information unless you've got a really good relationship. Quite often we've } \\
\text { got to go in and broker that. At DoArt we can go in and broker relationships for people'. (Dorothy) }\end{array}$ & $\begin{array}{l}\text { Broker } \\
\text { Position }\end{array}$ & \multirow{3}{*}{$\begin{array}{l}\text { Influential } \\
\text { Network } \\
\text { Position }\end{array}$} \\
\hline $\begin{array}{l}\text { AGM Minutes: 'Drawn from industries across the cultural sector, DoArt's new board members are experts in various } \\
\text { fields, including the arts, policy and research development, funding, design ... and digital media.' }\end{array}$ & $\begin{array}{l}\text { Authoritative } \\
\text { Advisors }\end{array}$ & \\
\hline $\begin{array}{l}\text { 'Power is attributed, I have no illusions - if I was not in this role [network broker], then I would not get any of these } \\
\text { invites. And the kind of things you get invited to is where the power is in Scotland.' (Emily) }\end{array}$ & Power Base & \\
\hline $\begin{array}{l}\text { 'When we were there [event] we set up a Facebook page ... so we were able to keep in touch and ... establish } \\
\text { personal relationships with ... people who are in similar organisations, similar issues, and I feel that ... if I had a } \\
\text { problem ... then I could speak to them because they know me quite well [now]'. (Jennifer) }\end{array}$ & $\begin{array}{l}\text { Peer Support } \\
\text { Development }\end{array}$ & \multirow{3}{*}{$\begin{array}{l}\text { Enhanced } \\
\text { Social Capital }\end{array}$} \\
\hline $\begin{array}{l}\text { 'I tend to get asked to things ... increasingly, recently. I think it was due to the participation in the network research } \\
\text { group ... I seem to have been allowed to become involved in other things'. (Cristie) }\end{array}$ & \begin{tabular}{|l|} 
Improved \\
Network Access
\end{tabular} & \\
\hline $\begin{array}{l}\text { 'There were quite a lot of Scottish people there [networking event], from Scottish theatres and organisations, but } \\
\text { also Welsh, English, and so on ... that helped to establish really good relationships with representatives that were } \\
\text { there from ... [large] member organisations'. (Jennifer) }\end{array}$ & $\begin{array}{l}\text { Group } \\
\text { Membership } \\
\text { Expansion }\end{array}$ & \\
\hline $\begin{array}{l}\text { 'Our reputation has grown for certain things like ... doing what we said we were going to do ... it is a kind of self- } \\
\text { policing thing now'. (Emily) }\end{array}$ & $\begin{array}{l}\text { Growing } \\
\text { Reputation }\end{array}$ & \multirow{3}{*}{$\begin{array}{l}\text { Enhanced } \\
\text { Symbolic } \\
\text { Capital }\end{array}$} \\
\hline $\begin{array}{l}\text { 'There is one [famous] person ... now she loves us and she tells everybody about us, but if we were on her wrong } \\
\text { side, we would probably be down the pan by now'. (Dorothy) }\end{array}$ & \begin{tabular}{|l|l|l} 
Famous \\
Supporters
\end{tabular} & \\
\hline Website: 'Our work for has been nominated for a Scottish Design Award' & Major Awards & \\
\hline $\begin{array}{l}\text { 'I have been nominated as the Data Champion ... for a project that the Arts Council in England are running ... I } \\
\text { have been [invited] ... in case Scotland decides to do it'. (Cristie) }\end{array}$ & Respect & \multirow{3}{*}{ Legitimacy } \\
\hline $\begin{array}{l}\text { 'It has changed since we have been on the go ... there is a national companies meeting, which gets all the big dudes } \\
\text { together. There was one the other day and Emily ... got a phone call the next day from one of the other people at the } \\
\text { session, saying what can we do to help him'. (Dorothy) }\end{array}$ & Recognition & \\
\hline $\begin{array}{l}\text { 'A few weeks ago, there were people over here from Holland ... because Glasgow was such a good model and we } \\
\text { were the only people who used [method] to benchmark audience data and he [contact] invited them over here for us } \\
\text { to do a presentation on what my data says and what it means'. (Cristie) }\end{array}$ & $\begin{array}{l}\text { Role Model } \\
\text { Status }\end{array}$ & \\
\hline
\end{tabular}

